\title{
Clotted Specimen
}

National Cancer Institute

\section{Source}

National Cancer Institute. Clotted Specimen. NCI Thesaurus. Code C78724.

A specimen that has become coagulated. 